\title{
GENETIC DIVERSITY BARLEY AND OATS OF N.I. VAVILOV ALL-RUSSIAN RESEARCH INSTITUTE OF PLANT INDUSTRY COLLECTIONS FOR BREEDING
}

\author{
Igor G. Loskutov*,**, Olga N. Kovaleva*, and Elena V. Blinova* \\ * N.I. Vavilov All-Russian Research Institute of Plant Industry, 42-44 B. Morskaya Street, St. Petersburg, 190000, RUSSIA; \\ i.loskutov@vir.nw.ru \\ ** St. Petersburg State University, 7-9 Universitetskaya nab.,St. Petersburg, 199034, RUSSIA
}

Communicated by Isaak Rashal

The paper summarises long-term data on the collection of cereal forage crops (barley, oat) studied under diverse conditions at experimental stations of the N. I. Vavilov All-Russian Research Institute of Plant Industry. The selected sources of economically important traits that can be used in cereal forages breeding are presented.

Key words: barley, oat, sources, donors, economically important traits.

\section{INTRODUCTION}

Creation of new agricultural crop cultivars possessing a complex of important traits, high yielding ability and product quality under different environmental conditions requires well-studied initial material. The problem of selecting the most promising parental forms for crossing from the available genetic diversity of crop plants still remains one of the most difficult and responsible issues in the breeding process.

Cereal forage crop breeding is mainly aimed at raising cultivar grain productivity. Also, duration of the vegetation period of a plant is directly linked with grain yield, its quality and seed sowing qualities. Therefore, in terms of productivity, the mid-early and mid-season cultivars of grain forage crops would be the best in terms of productivity. A potentially high grain yield of agricultural crops should be combined with other economically important traits and resistance to biotic and abiotic factors (Лукьянова и др., 1990; Родионова и др., 1994). Diseases not only suppress plants and reduce the size of grains and yields per unit area, but also deteriorate the yield quality through the accumulation of pathogen waste products. Mycotoxins decrease the cost and consumption properties of oat and barley grain and adversely influence human and animal health. The problem of creating cultivars resistant to main diseases becomes of primary importance, since it is the safest way of disease control. Only the availability of adequate initial material will make it possible to successfully solve these and the newly arising problems in breeding. Identification of sources of the main economically important traits is one of the tasks of studying the global diversity of barley and oat accumulated in collections of the Department of Oat, Rye and Barley Ge- netic Resources at the N.I. Vavilov All-Russian Research Institute of Plant Industry (VIR) (Лоскутов, 2007; Лоскутов и др., 2007).

Collections of grain forage crops at the Vavilov Institute of Plant Industry serve as the main source providing new initial material to breeding programmes aimed at creating new cultivars. The long-term efforts exerted to collect the global diversity at the Institute have resulted in barley and oat collections that are among the largest in Europe. They number about 18000 accessions of barley and over 12000 oat accessions of different geographical origin (Лоскутов, 2009; Loskutov and Rines, 2011).

\section{AGRONOMICAL TRAITS}

Studies of the grain forage crops collections are centred on the complex analysis of accessions concerning the main economically important traits and are aimed at the identification of sources and donors of the traits employing VIR guidances (Лукьянова и др., 1973; Лоскутов и др., 2012). The resulting accessions are supplied to the breeding centres where they are successfully used in breeding of new grain forage crop cultivars.

The barley and oat collections of VIR are studied in field conditions at experimental stations of the Institute, most of which are located in the main zones of agricultural crop cultivation (Лоскутов, Ковалева, 2007).

The Department of Oat, Rye and Barley Genetic Resources of VIR widely applies the methods of the initial material joint study to meet necessities of common and new trends in breeding that take shape due to global climatic and 
phytopathological changes and due to new quality demands in grain processing for food and forage (Лоскутов, 1999; Лоскутов, 2009). Researchers from the Department carry out their investigations in close cooperation with their colleagues from the VIR departments of Biochemistry and Molecular Biology, Plant Physiology, Genetics and from the Laboratory of Plant Immunity. Also, cooperation with other Russian and foreign research partner at the Institutes is given much attention when seeking for quality scientific results (Лоскутов, 2007; Лоскутов и др., 2007).

The staff of VIR has recently performed a large number of systematic studies of the newly acquired global crop diversity. A versatile analysis of this new material applying all the available methods resulted in the identification of new sources for all of the studied economically important traits.

An extensive interest in genetic studies of barley and oat has provided a basis for the establishment at VIR of genetic stocks collections comprised of cultivars, cultivated lines and wild species with one or more identified genes govern- ing different morphological, agrobiological, biochemical and other traits. The greater part of the collection is represented by accessions carrying the genes of resistance to various diseases (Лоскутов и др., 1997).

The most important factors influencing duration of the vegetation period of a plant, especially its first part, are light, day duration and temperature regime. The results of longterm studies performed together with the Department of Plant Physiology of VIR have discovered a variety of responses to photoperiod and vernalisation (Tables 1 and 2). Among the recently identified barley and oat accessions that were insensitive to photoperiod were forms from the American continents (Кошкин и др., 2010; Лоскутов, 2007; Лоскутов и др., 2007).

The issue of dwarfness is closely linked to the problem of lodging resistance in cereals, and occupies a special place among the breeding objectives for these crops. Investigations of the oat genetic collection performed in recent years have identified accessions that combine semi-dwarf with a

CHARACTERISTICS OF OAT ACCESSIONS FOR DAY LENGTH INSENSITIVE (Cph), 2012

\begin{tabular}{|c|c|c|c|c|c|c|}
\hline \multirow{2}{*}{$\begin{array}{c}\text { No. catalogue } \\
\text { VIR }\end{array}$} & \multirow[t]{2}{*}{ Origin } & \multirow[t]{2}{*}{ Accession } & \multicolumn{2}{|c|}{ Period germination - heading, days } & \multirow{2}{*}{$\mathrm{T}_{2}-\mathrm{T}_{1}$} & \multirow[t]{2}{*}{$\mathrm{Cph}$} \\
\hline & & & long day, $\mathrm{T}_{1}$ & short day, $\mathrm{T}_{2}$ & & \\
\hline 12230 & Mexico & Chihuahua. st & $38.5 \pm 0.81$ & $47.3 \pm 0.42$ & 8.8 & 1.23 \\
\hline 7751 & Turkey & Local & $37.4 \pm 0.82$ & $43.4 \pm 0.67$ & 6.0 & 1.16 \\
\hline 11207 & USA & Burnett & $41.3 \pm 1.04$ & $56.3 \pm 5.82$ & 15.0 & 1.36 \\
\hline 11801 & Peru & D $95 \mathrm{E} \mathrm{P}_{2}$ & $40.2 \pm 1.45$ & $52.3 \pm 2.19$ & 12.1 & 1.30 \\
\hline 12235 & -“- & Desnuda & $40.3 \pm 0.56$ & $76.4 \pm 9.58$ & 36.1 & 1.90 \\
\hline 12614 & Ethiopia & IAR 376 & $41.6 \pm 0.76$ & $62.1 \pm 3.56$ & 20.5 & 1.49 \\
\hline 13467 & Mexico & HUA "S"- 4 & $41.1 \pm 0.46$ & $65.9 \pm 5.47$ & 24.8 & 1.60 \\
\hline 15153 & USA & B $525-336$ & $38.8 \pm 0.61$ & $48.5 \pm 0.68$ & 9.7 & 1.25 \\
\hline 15216 & -“- & P. T. 629063 & $38.7 \pm 0.26$ & $48.9 \pm 0.52$ & 10.2 & 1.26 \\
\hline 15257 & -“ & PA $7836-416$ & $41.2 \pm 0.20$ & $66.8 \pm 5.50$ & 25.6 & 1.62 \\
\hline 15258 & -“- & PA $7836-2701$ & $38.8 \pm 0.20$ & $71.9 \pm 6.68$ & 33.1 & 1.85 \\
\hline 15262 & -“- & PA $7967-3145$ & $38.4 \pm 1.46$ & $49.2 \pm 2.45$ & 10.8 & 1.28 \\
\hline 15267 & -“- & IN 09201 & $37.7 \pm 0.40$ & $48.8 \pm 0.49$ & 11.1 & 1.29 \\
\hline
\end{tabular}

$\overline{\mathrm{Cph} \text {, coefficient }}$ of photoperiodic sensitive

CHARACTERISTICS OF BARLEY ACCESSIONS FOR DAY LENGTH INSENSITIVE (Cph), 2012

\begin{tabular}{|c|c|c|c|c|c|c|}
\hline \multirow{2}{*}{$\begin{array}{c}\text { No. catalogue } \\
\text { VIR }\end{array}$} & \multirow[t]{2}{*}{ Origin } & \multirow[t]{2}{*}{ Accession } & \multicolumn{2}{|c|}{ Period germination - heading, days } & \multirow[t]{2}{*}{$\mathrm{T}_{2}-\mathrm{T}_{1}$} & \multirow[t]{2}{*}{$\mathrm{Cph}$} \\
\hline & & & long day, $\mathrm{T}_{1}$ & short day, $\mathrm{T}_{2}$ & & \\
\hline 18095 & Hungary & Bankuti Korai, st & $38.6 \pm 0.54$ & $38.3 \pm 0.92$ & -0.3 & 1.00 \\
\hline 30749 & Russia & Impuls 90 & $41.7 \pm 0.47$ & $41.8 \pm 0.49$ & 0.1 & 1.00 \\
\hline 21799 & Australia & Weeah & $37.1 \pm 1.29$ & $42.2 \pm 0.36$ & 5.1 & 1.14 \\
\hline 23351 & -“" & Australische & $36.4 \pm 0.75$ & $45.1 \pm 1.21$ & 8.7 & 1.24 \\
\hline 29836 & Russia & Gandvig & $47.0 \pm 0.65$ & $60.3 \pm 2.92$ & 13.3 & 1.28 \\
\hline 29808 & -“- & Kornet & $47.1 \pm 0.77$ & $65.2 \pm 2.67$ & 18.1 & 1.38 \\
\hline 27563 & Finland & Jo 1310 & $50.6 \pm 1.18$ & $67.3 \pm 2.85$ & 16.7 & 1.33 \\
\hline 30173 & Canada & Buch & $47.5 \pm 1.11$ & $60.8 \pm 2.92$ & 13.3 & 1.28 \\
\hline 30265 & -“'- & Sumko & $45.9 \pm 0.18$ & $66.5 \pm 2.13$ & 20.6 & 1.45 \\
\hline
\end{tabular}

Cph, coefficient of photoperiodic sensitive 
LARGE-SIZE GRAIN OAT ACCESSIONS, LENINGRAD REGION, 2008-2012.

\begin{tabular}{|c|c|c|c|c|c|c|}
\hline \multirow{2}{*}{$\begin{array}{c}\text { No. catalogue } \\
\text { VIR }\end{array}$} & \multirow[t]{2}{*}{ Origin } & \multirow[t]{2}{*}{ Accession } & \multirow{2}{*}{$\begin{array}{l}\text { Vegetetive period, } \\
\text { days }\end{array}$} & \multirow[t]{2}{*}{1000 grain weight, $\mathrm{g}$} & \multicolumn{2}{|c|}{ Weight of grains $1 \mathrm{~m}^{2}$} \\
\hline & & & & & $\mathrm{g}$ & $\%$ of standard \\
\hline \multicolumn{7}{|l|}{$2008-2010$} \\
\hline 14898 & USA & IL 2838 & $82.3 \pm 5.1$ & $52.3 \pm 5.1$ & $330.0 \pm 157.3$ & 60.4 \\
\hline \multicolumn{7}{|l|}{ 2009-2011 } \\
\hline 14921 & Chine & Y4 & $84.0 \pm 12.8$ & $58.0 \pm 5.8$ & $193.3 \pm 151.1$ & 34.3 \\
\hline 14916 & Chine & AC Pinnacle & $93.3 \pm 2.4$ & $54.5 \pm 5.6$ & $335.0 \pm 155.8$ & 61.2 \\
\hline 14917 & Canada & AC Ronald & $105.0 \pm 2.8$ & $55.8 \pm 9.2$ & $430.0 \pm 154.9$ & 77.1 \\
\hline \multicolumn{7}{|l|}{ 2010-2012 } \\
\hline 14988 & Canada & OA 313 & $79.7 \pm 4.6$ & $63.5 \pm 9.6$ & $513.3 \pm 196.3$ & 86.9 \\
\hline 14989 & Canada & IA 338 & $83.7 \pm 6.6$ & $56.6 \pm 6.8$ & $428.3 \pm 159.8$ & 69.5 \\
\hline 14990 & Canada & $\overline{\mathrm{I}} \mathrm{A} z 272$ & $81.0 \pm 9.7$ & $59.4 \pm 9.1$ & $408.3 \pm 158.9$ & 62.9 \\
\hline
\end{tabular}

high grain productivity of the panicle and good grain quality, and can be recommended for use in breeding (Лоскутов, 2007, Лоскутов и др., 2007; Loskutov, 2010).

Plant productivity is composed of several elements, namely, the number of spikelets and grain per spike or panicle, grain mass per ear or panicle, grain mass per plant, and 1000grain weight (Table 3). Selected cultivars have been found to have high ear or panicle productivity. The accessions identified for their high 1000-grain weight showed a value over 50 g (Лоскутов, Ковалева, 2011; Смирнова, Лоскутов, 2011).

The main character grain weight per area unit is a complex index of productivity that significantly varies depending on the growing conditions and cultivar peculiarities (Смирнова, Лоскутов, 2011).

\section{DISEASE RESISTANCE}

A complex phytopathological evaluation of all the specific diversity of Avena facilitated identification of new sources and donors of resistance that can be used for broadening the genetic basis of newly created oat and barley cultivars. A strong natural infectious background allows to evaluate resistance of accessions to diseases in field conditions. Crown rust affects oat crops each year during the ear formation-ripening stage. Screening in the field has identified a set of barley accessions that displayed resistance under strong infectious stress. A study of the barley collection resulted in the identification of a series of sources of complex resistance to loose and covered smuts. Helminthosporium blight is known to annually affect oat and barley crops to a varying degree. Barley yellow dwarf virus (BYDV) is a very harmful disease that can lead to total death of plants (Лоскутов, 2007; Лоскутов, Ковалева, 2007; Лоскутов и др., 2007; Лоскутов, Ковалева, 2011).

Together with the All-Russian Institute of Plant Protection (VIZR, Russia) and American colleagues from the Univer- sity of Minnesota (USA) sources of resistance to the most harmful strain of stem rust (Ug99) have been selected from commercialised barley cultivars (Лоскутов, Ковалева, 2011).

Joint investigations of spring barley performed together with American colleagues from the University of Minnesota and of oat performed together with VIZR (Russia) resulted in the identification of sources of grain resistance to Fusarium Head Blight and mycotoxin contamination in caryopses within both crops. It has been found that the highest degree of resistance is displayed by naked barleys and oats, but single resistant accessions have also been identified among hulled barleys and oats. The most promising in terms of multicomponent resistance to FHB were found to be oat landraces originating from the Far East of Russia and Asia continent, and resistance to Fusarium infection has been found in productive naked oat and barley cultivars (Dahl et al., 2009; Gavrilova et al., 2011).

\section{QUALITY COMPONENTS}

Due attention is paid to the study of traditional biochemical parameters. A study of a set of barleys performed together with the Department of Biochemistry and Molecular Biology of VIR has identified high-protein accessions from Uzbekistan, Tajikistan, Iran, Afghanistan, India and Ethiopia (Батакова и др., 2010).

The most important biochemical components that increase nutritive value of oat include protein, fats, $\beta$-glucans, tocopherols, sterols and other components. At present, this trend in studies of the collection is the most promising one. A set of oat cultivars has been analysed for oil content in the caryopsis and its fatty acid composition. This work was conducted together with the Department of Biochemistry and Molecular Biology of VIR. Some accessions had over $7 \%$ of oil in the caryopsis; these were some local naked oats from China, Mongolia, Great Britain and Russia, and several hulled oat accessions from different countries. Regard- 
ing fatty acid composition, it should be noted that almost all studied accessions had a level of oleic acid content as high as that in sunflower. It was above $40 \%$ in some accessions from China, Spain, Great Britain and Russia. Also, a high content of palmitic, oleic and linoleic acids was demonstrated by cultivars of naked oat (Лоскутов и др., 2007; Loskutov, 2010).

Some accessions of spring naked barley have been analyzed for $\beta$-glucans content. This work, performed together with the Baltika Brewery Company (St-Petersburg, Russia), has shown that two-row barleys had a content of this component that was on average 1.5 times higher than in six-row barleys. Also, joint investigations with the Protein+ Company have resulted in the identification of sources of $\beta$-glucan, a non-starch polysaccharide, in oat accessions. Barley and oat with the above-mentioned high quality values can be effectively used in the production of combined feeds, as well as in the food industry, especially for dietary food manufacturing (Батакова и др., 2010; Лоскутов, Ковалева, 2011).

\section{CONCLUSIONS}

The complex field evaluation combined with the analysis performed together with methodological laboratories of VIR makes it possible to select valuable genetic material required for solving burning issues of breeding in different regions of the country.

In summary, collections of cereal forages at VIR serve as the main source of initial material required to meet the needs of the main trends in breeding of said crops. The identified barley and oat sources have been sent to over 25 breeding centres in the Russian Federation for breeding new productive cultivars of cereal forages.

\section{REFERENCES}

Dahl, S. K., Bockelman, H. E., Loskutov, I. G., Kovaleva, O. N. et al. (2009). Identification of FHB Resistance in Hordeum. Proceedings of the US Wheat and Barley Scab Initiative Forum (p. 11). Orlando.

Gavrilova, O., Gagkaeva, T., Loskutov, I., Yli-Mattila, T. (2011). Evaluation of oat germplasm for resistance to Fusarium head blight. J. Plant Breed. Seed Sci., 64, 15-22.

Loskutov, I. G. (1999). Vavilov and His Institute. A History of the World Collection of Plant Resources in Russia. IPGRI. Rome. 190 pp.

Loskutov, I. G. (2010). Genetic resources and main directions and results of barley and oat breeding in Russia. Agron. Res., 8 (3), 673-680.

Loskutov, I. G., Rines, H. (2011). Avena L. In: Wild Crop Relatives: Genomic \& Breeding Resources (pp. 109-184). Kole, C. (Ed.). Heidelberg, Berlin, New York: Springer.

Батакова О. Б., Хорева В. И., Ковалева О. Н., Лоскутов И. Г. (2010). Источники скороспелости и качества зерна ярового ячменя для условий Европейского севера России [Sources of earliness and grain quality of spring barley under condition of European north of Russia]. Агро XXI, № 4-6 (in Russian).

Кошкин В. А., Лоскутов И. Г., Матвиенко И. И., Смирнова Л. О., Звейнек И. А., Блинова Е. В., Ковалева О. Н., Терентьева И. А. (2010). Ячмень и овес. Характеристика образцов по фотопериодической чувствительности [Barley and Oat. Characteristic of Accessions to Photoperiodic Response]. Каталог мировой коллекиии ВИР, вып. 801. (с. 37). Санкт-Петербург: ВИР (in Russian).

Лоскутов И. Г. (2007). Овес (Avena L.). Распространение, систематика, эволюция и селекционная ценность [Oat (Avena L.). Distribution, Taxonomy, Evolution and Breeding Value]. Санкт-Петербург: ВИР. 336 с. (in Russian).

Лоскутов И. Г. (2009). История мировой коллекции генетических ресурсов растений в России [The History of the World Collection of Plant Genetic Resources in Russia]. Санкт-Петербург: ВИР. 294 с. (in Russian).

Лоскутов И. Г.. Кобылянский В. Д., Ковалева О. Н. (2007). Итоги и перспективы исследований мировой коллекции овса, ржи и ячменя [Results and perspectives of research of global oat, rye and barley collections]. Труды прикл. бот., ген. сел. (Санкт-Петербург), 164, 80-100 (in Russian).

Лоскутов И. Г., Ковалева О. Н., Блинова Е. В. (2012). Методические указания по изучению и сохранению мировой коллекции ячменя и овса [Methodological Guidance Directory for Studying and Maintaining VIR's Collections of Barley and Cat]. Санкт-Петербург: ВИР. 63 с. (in Russian).

Лоскутов И. Г., Ковалева О. Н. (2007). Источники хозяйственно ценных признаков для селекции ячменя [Sources valuable characters for barley breeding]. В кн.: Сборник трудов конференции «Современные принципы и методы селекции ячменя», Краснодар (с. 129-133). Краснодар (in Russian).

Лоскутов И. Г., Ковалева О. Н. (2011). Роль совместных исследований в селекции зернофуражных культур [Role of joint research for breeding of cereal crops]. Зерновое хозяйство России, № 3 (15), 27-33 (in Russian).

Лоскутов И. Г., Мережко В. Е. (1997). Овес. (Образцы с идентифицированными генами, контролирующими морфологические и хозяйственно-ценные признаки) [Oat. (Samples with Identified Genes for Biological, Morphological, and Commercially Valuable Traits)]. Каталог мировой коллекции ВИР, вып. 686. Санкт-Петербург: ВИР. 83 с. (in Russian).

Лукьянова М. В., Трофимовская А. Я., Гудкова Г. Н., Терентьева И. А., Ярош Н. П. (1990). Культурная флора СССР. Т. 2. Ч. 2. Ячмень. [Cultivated Flora of the USSR. Vol. 2, Part 2. Barley]. 2-е изд. Ленинград: Колос. 421 с. (in Russian).

Лукьянова М. В., Родионова Н. А., Трофимовская А. Я (1973). Методические указания по изучению мировой коллекции ячменя и овса [Methodological Guidance Directory for Studying VIR's Collections of Barley and Oats]. Ленинград. 29 с. (in Russian).

Родионова Н. А., Солдатов В. Н., Мережко В. Е., Ярош Н. П., Кобылянский В. Д. (1994). Культурная флора. Т. 2. Ч. 3. Овес [Cultivated Flora. Vol. 2. Part 3. Oat]. Москва: Колос. 367 с. (in Russian).

Смирнова Л. О., Лоскутов И. Г. (2011). Скороспелость и особенности формирования продуктивности овса в условиях Северо-Запада РФ [The earliness and features formation of productivity of oat under condition North-West of Russian Federation]. Вестник Санкт-Петербургского аграрного университета, № 24, 27-32 (in Russian).

Received 14 November 2012

\section{N. VAVILOVA VISKRIEVIJAS AUGKOPĪBAS INSTITŪTA MIEŽU UN AUZU KOLEKCIJAS SELEKCIJAS VAJADZĪBĀM}

Sniegtas ziņas par miežu un kviešu paraugiem no N. Vavilova Viskrievijas Augkopības institūta kolekcijas, kuri būtu izmantojami šo augu ekonomiski svarīgu pazīmju selekcijā. 